\title{
OPEN Publisher Correction: Identification of microRNAs and relative target genes in Moringa oleifera leaf and callus
}

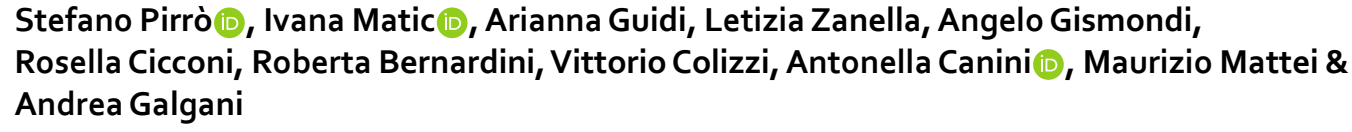

Correction to: Scientific Reports https://doi.org/10.1038/s41598-019-51100-4, published online 22 October 2019

The original version of this Article contained errors in the spelling of the authors Stefano Pirrò, Ivana Matic, Arianna Guidi, Letizia Zanella, Angelo Gismondi, Rosella Cicconi, Roberta Bernardini, Vittorio Colizzi, Antonella Canini, Maurizio Mattei \& Andrea Galgani which were incorrectly given as Pirrò Stefano, Matic Ivana, Guidi Arianna, Zanella Letizia, Gismondi Angelo, Cicconi Rosella, Bernardini Roberta, Colizzi Vittorio, Canini Antonella, Mattei Maurizio \& Galgani Andrea respectively.

These errors have now been corrected in the PDF and HTML versions of the Article.

(c) (i) Open Access This article is licensed under a Creative Commons Attribution 4.0 International License, which permits use, sharing, adaptation, distribution and reproduction in any medium or format, as long as you give appropriate credit to the original author(s) and the source, provide a link to the Creative Commons license, and indicate if changes were made. The images or other third party material in this article are included in the article's Creative Commons license, unless indicated otherwise in a credit line to the material. If material is not included in the article's Creative Commons license and your intended use is not permitted by statutory regulation or exceeds the permitted use, you will need to obtain permission directly from the copyright holder. To view a copy of this license, visit http://creativecommons.org/licenses/by/4.0/.

(C) The Author(s) 2019 